\title{
CHARACTERIZATION OF ACTIVE LANDFILL LEACHATE AND ASSOCIATED IMPACTS ON EDIBLE FISH (ORECHROMIS MOSSAMBICUS)
}

\author{
*Emenike C.U, Fauziah S.H, Agamuthu P.
}

Institute of Biological Sciences, University of Malaya, 50603 Kuala Lumpur, Malaysia

* ceejayscopy@yahoo.com (Corresponding author)

Received on $19^{\text {th }}$ July 2011 , accepted in revised form $21^{\text {st }}$ July 2011

\begin{abstract}
Fish is an organism of both ecological and economic importance. Its existence in the water helps to sustain aquatic ecosystem via energy transfer. However, pollution can serve as a deterrent to its survival. Leachate from landfills and open dumps are generated due to waste deposition and associated water percolation which finds its way into water courses or even aquifer. Therefore this study was designed to characterize raw leachate from an active landfill and subsequently assess its potential impacts on edible fish, Orechromis mossambicus. The physico-chemical analysis of the leachate showed almost a neutral acid-base ratio $(\mathrm{pH} 7.35 \pm 0.6)$, with corresponding 27,000 and $51,200 \mathrm{mg} / \mathrm{L}$ for $\mathrm{BOD}_{5}$ and $\mathrm{COD}$, respectively. Low ammonium content was recorded $(0.09 \mathrm{mg} / \mathrm{L})$ while the concentrations of some metals namely $\mathrm{Zn}(828 \mathrm{mg} / \mathrm{L}), \mathrm{Cr}(25 \mathrm{mg} / \mathrm{L}), \mathrm{Ni}(19.5 \mathrm{mg} / \mathrm{L})$ exceeded allowable effluent discharge limits according to the Malaysia EQA 1974 Standards. The deep black colouration of the raw leachate was associated with high concentration of total dissolved solids $(1,730 \mathrm{mg} / \mathrm{L})$. Five different concentrations of the leachate $(2.5-3.8 \% \mathrm{v} / \mathrm{v})$ based on the range finding test, were applied definitively to obtain the effluent's lethal concentration $\left(\mathrm{LC}_{50}\right)$ on the named fish. Acute toxicity test of the raw leachate on O.mossambicus via static method revealed an $\mathrm{LC}_{50}$ of $3.2 \% \mathrm{v} / \mathrm{v}$ as calculated using Finney's probit analysis from EPA. Mortality rate of the fish increased with increase in leachate concentration. It shows that the presence of some of the aforementioned components like $\mathrm{BOD}_{5}, \mathrm{COD}$ and even the metals in the leachate is not ideal since that reflects potential toxic compounds. The fish mortality observed in the research can be attributed to the physicochemical constituents of the landfill leachate. This study concludes that based on characterization, leachate generated from landfills contain potentially toxic components. These constituents of leachate made it very dangerous for edible fish like O.mossambicus as it caused its mortality.
\end{abstract}

(Key words: Leachate, Landfill, Fish, Orechromis mossambicus, Toxicity).

\section{INTRODUCTION}

The ecosystem has its base on three components namely; soil water and air, and as such any form of impairment on one of them may disrupt the flow of interaction in nature. Aquatic system is very crucial in maintaining ecological balance and harbors organisms that are of very significant importance to humans. Fish is not just seen as the dominant organism resident in most waters but is vital for enhancing the energy flow in the ecosystem since it is edible food for humans in most cases. However, it may even serve as an indicator for degree of impacts of some anthropogenic activities that disrupt the ecosystem. The process by which fish consumes organisms is a salient aspect that regulates trophic structure. This therefore enhances the stability, resilience, and food web dynamics of aquatic systems
[1]. Its ecological and economic importance cannot be over emphasized. In fact much effort has been devoted to establishing relationships (statistically) between reef fish communities and the various features of their habitat [2], as such avails researchers the ecological details which enhance hypothetical postulates for future investigations. Such investigations become necessary since fish survival are negatively affected by multiple anthropogenic interruptions such as pumping, dredging, fishing and excessive pollution [3]. Being food for humans and source of income, its economic importance is very pronounced.

The survival and metabolic activities of aquatic organisms including fish is influenced by the presence of contaminants brought about by anthropogenic disturbances. This includes landfilling activities. Landfilling being one of the waste 
management options is not devoid of negativity. Approximately, $75 \%$ of solid waste generated in Malaysia is sent to landfill [4], as these landfills are either sanitary or non-sanitary. In fact in various parts of the globe, landfilling is very common in the waste management hierarchy. This pose significant pressure on the environment as the leachate produced from the landfills contaminate streams, rivers and other water bodies due to the lethal migration of leachate [5], especially when there are no liners or in situation of broken liners.

It is not easy to assess the potency and degree at which leachate poses risk to groundwater, soil and even aquatic life, due to its varying composition. The varying composition is consequent on the type of waste materials deposited at the landfill. Most times it can be in the form of dissolved organic matters like alcohols, acids, aldehydes and short chain sugars, or heavy metals, hydrocarbons compounds, and inorganic macro components [6]. Study by Christensen [7], analyzed that leachate contains high concentrations of biological oxygen demand (BOD) and chemical oxygen demand (COD), xenobiotic organic compounds (XOCs), ammonia, heavy metals and other materials that are toxic. In fact, municipal landfill leachate has been characterized of more than 200 organic compounds [8] and of these compounds, about 35 are potentially dangerous to the human health and the immediate environment [9]. A high ammonia level is very detrimental to many living organisms in surface water and leads to eutrophication and dissolved oxygen (DO) depletion [10]. The volume of leachate generated from waste dump depends on the initial water content of the municipal solid waste, the condition of storage and disposal conditions like temperature, humidity and ventilation [11].

Based on the aforementioned factors, it becomes imperative to evaluate the impact of landfill leachate on aquatic organisms via toxicological approach to ensure safe/sustainable discharge of leachate from landfills. Though chemical oxidation of leachate had been employed to assess the early stabilization of landfills, yet most by-products are not easily detected via chemical analysis; hence the recent use of toxicological evaluation to assess the changes in leachate quality [12]. Different studies had been carried out to evaluate the risk impacts of landfill leachate using Cyprinus caprio, zebra fish (Brachydanio rerio), Japanese Medeka (Oryzias latipes) and tilapia (Sarotherodon mossambicus) [5, 13, 14, 15]. However, some of such studies showed some variations in the result due to differences in fish size, wet weight and length, species etc.
Orechromis mossambicus (tilapia) which is of high market demand for its edible nature is also vulnerable to leachate contamination. Therefore, this study was aimed at characterizing raw leachate from an active sanitary landfill with a view to evaluating its degree of risk on O.mossambicus.

\section{MATERIALS AND METHODS}

\section{Specimen/sample collections and preparations}

O.mossambicus with an average length of $3.4 \pm 0.2 \mathrm{~cm}$ and $2.52 \pm 0.3 \mathrm{~g}$ of wet weight were obtained from commercial aqua farm. Having transported it to the laboratory within 45 minutes of purchase, the fish were acclimatized in aquarium for 14 days. Temperature of the aquarium was maintained at 27.3 $-28.2^{\circ} \mathrm{C}$ with $\mathrm{pH} 7.2-8.0$ and DO at $7.3-8.2 \mathrm{mg} / \mathrm{L}$. Fish were fed with food pellet and feeding stopped 48 hours prior to the toxicity test [16], as this was to reduce metabolic wastes during the experiment. Light and dark photoperiods were set at 12 hours each while proper measures were taken to ensure less than $5 \%$ mortality prior to its toxicity testing.

Leachate samples were collected at different times from an active sanitary landfill in Malaysia, Jeram Sanitary Landfill (JSL), which is 4 years old. Samespot collection approach was used to ensure proper replication of sample regardless of the varying days of collection.

\section{Leachate characterization}

The leachate sample was analyzed on the spot for some parameters like colour, pH (HANNA HI 8424) and odour. Physico-chemical properties analyzed were $\mathrm{BOD}_{5}$ and $\mathrm{COD}$ using APHA Standard Methods [16] while other parameters analyzed were metals, volatile fatty acids, monocyclic aromatic hydrocarbons, semivolatile organic carbon, organophosphorus pesticides and alcohols via inductively-coupled plasma mass spectrometry (ICPMS) and gas chromatohraphy and mass spectrometry (GC-MS) methods [16, 17].

\section{Toxicity Test}

The laboratory static test was introduced while evaluating the toxicity of leachate on O.mossambicus. Randomly selected groups of 10 fish (with replicates) were transferred into the test tank (25L capacity) while maintaining fish weight to 
water ratio at an average of $1.0 \mathrm{~g} / \mathrm{L}$. Finally, 5 concentrations of the raw leachate $(2.5,2.8,3.1,3.4$ and $3.8 \% \mathrm{v} / \mathrm{v}$ ) were adopted after conducting range finding test. A control experiment which comprised of fish without leachate exposure was used as a check in the test. Aeration pumps were not used so as to prevent formation of scum which will limit the penetration and circulation of oxygen in the experiment. Zero mortality was ensured in the control group; while dead fish in the exposed group were taken out almost immediately to avoid depletion of DO. The experiment was monitored 12 hourly for 96 hours. Finney's Probit method was used to generate the median lethal concentration $\left(\mathrm{LC}_{50}\right)$ of the raw leachate sample on O.mossambicus.

\section{RESULT AND DISCUSSION}

\section{Characterized Leachate}

Table 1 shows the physico-chemical properties of the raw leachate obtained from JSL. Visual appearance showed a deep black colouration of the raw leachate which may be associated to the waste composition and suspended matter within. The slightly ammoniac odour reflected in the $\mathrm{NH}_{3}-\mathrm{N}$ concentration (0.09 $\mathrm{mg} / \mathrm{L})$ implied that biodegradation of amino acids and other nitrogenous organic matter in the landfill leachate might still be at the early stage of stabilization. The $\mathrm{pH}$ value of leachate was pH7.35 \pm 0.6 indicating a typical of mature landfill whose leachate had not undergone stabilization [18, 4]. The BOD and COD levels (averagely 27,000 and $51,200 \mathrm{mg} / \mathrm{L}$ ) are reflection of high concentrations of degradable organic matters in the waste stream since JSL is still operational. Actually, the deposition of waste in the landfill avails presence of high concentration of dissolved organic matter and this reflects high concentration of total dissolved solids (TDS) $(1,730 \mathrm{mg} / \mathrm{L})$ and turbidity value $(4,150$ $\mathrm{mg} / \mathrm{L})$.

\section{Acute toxicity test}

The result of acute toxicity test of the leachate on O.mossambicus showed an increased trend of mortality with increase in leachate concentration. LC50 calculated using Finney's Probit analysis gave $3.2 \% \mathrm{v} / \mathrm{v}$. There was mortality at different intervals along the 96 hours of testing and the highest leachate concentration proved to be the most toxic to the fish while zero mortality was observed in the control group (Figure 1).

Though previous leachate study on tilapia (Sarotherodon mossambicus) had been carried out, yet the LC50 values were 1.4 and $12 \% \mathrm{v} / \mathrm{v}$ on two different sampling months [15]. Fish used in the present study belongs to class of tilapia as well and hence share common features and characteristics. However, the variation in LC50 in both studies may be associated to difference in fish size, slight species adaptability and leachate composition.

The toxicity of the leachate may be due to the high concentrations of BOD and COD which exceeded the standard limits for effluent discharge in Malaysia, at 50 and $100 \mathrm{mg} / \mathrm{L}$ respectively [19]. Though leachate toxicity is often associated with the presence of $\mathrm{NH}_{3}$ $\mathrm{N}$ but its low concentration makes it difficult to attribute it to the toxic impact on O.mossambicus in this study.

In fact, the nitrite concentration is high but its toxicity is often dependent on chloride to nitrite ratio [20]. Based on this study the chloride to nitrite ratio is high 86.58; hence may not be toxic as not less than chloride to nitrite ratios 17 for rainbow trout and 8 for fish of two economic importance are considered non-toxic [20].

Also, the presence of metals in leachate could have caused the mortality effect on O.mossambicus. Zn concentration which was $828 \mathrm{mg} / \mathrm{L}$ is enough to kill the fish, especially as the corresponding $\mathrm{Ca}$ content is low. Study by Svobodva et al [20], found that toxicity of $\mathrm{Zn}$ to fish was influenced by chemical characteristics of water; especially with toxicity of $\mathrm{Zn}$ being increased by the decrease in $\mathrm{Ca}$ concentrations. The study showed that $\mathrm{Zn}$ had a lethal concentration of $0.1 \mathrm{mg} / \mathrm{L}$ for Salmonids and $0.5-1.0 \mathrm{mg} / \mathrm{L}$ for Cyprinids. Other metals like $\mathrm{Fe}$ and $\mathrm{Ni}$ may inhibit the survival of fish [21].

Behaviourally, the exposed fish showed signs of restlessness during the experiment. Rapid movements by the fish and loss of equilibrium which were not observed in the control group proved to be an evidence of toxic impact of the leachate on the fish. Among other things to prove the toxic effect of the leachate were mucosal secretion within the gill region, gill hemorrhage and skin lightening of the exposed fish. 
Table 1. Physical-chemical properties of raw leachate from Jeram Sanitary landfill

\begin{tabular}{lrrr}
\hline Component & Unit & Quantity & Standard Limits \\
\hline Apparent colour & $\mathrm{NA}$ & Deep Black & NA \\
Odour & $\mathrm{NA}$ & Slightly ammoniac & $\mathrm{NA}$ \\
pH & $\mathrm{NA}$ & 7.35 & $5.5-9.0$ (EQA B) \\
Dissolved Oxygen & $\mathrm{mg} / \mathrm{L}$ & 5.8 & 40 (EQA B) \\
BOD & $\mathrm{mg} / \mathrm{L}$ & 27000 & 50 (EQA B) \\
COD & $\mathrm{mg} / \mathrm{L}$ & 51200 & 100 (EQA B) \\
TDS & $\mathrm{mg} / \mathrm{L}$ & 1,730 & $\mathrm{NA}$ \\
Chloride & $\mathrm{mg} / \mathrm{L}$ & 4150 & $\mathrm{NA}$ \\
Ammonical Nitrogen & $\mathrm{mg} / \mathrm{L}$ & 0.085 & 1 (EPA) \\
Nitrate Nitrogen & $\mathrm{mg} / \mathrm{L}$ & 38.6 & 10 (EPA) \\
Nitrite Nitrogen & $\mathrm{mg} / \mathrm{L}$ & 4.8 & 1 (EPA) \\
Mercury & $\mathrm{mg} / \mathrm{L}$ & 0.05 & 0.001 \\
Chromium & $\mathrm{mg} / \mathrm{L}$ & 25.27 & 0.005 \\
Zinc & $\mathrm{mg} / \mathrm{L}$ & 827.7 & 1 (EQA B) \\
Iron & $\mathrm{mg} / \mathrm{L}$ & 97.76 & 5 (EQA B) \\
Nickel & $\mathrm{mg} / \mathrm{L}$ & 19.50 & 1 (EQA B) \\
Ca & $\mathrm{mg} / \mathrm{L}$ & 20.17 & $\mathrm{NA}$ \\
BOD/COD & $\mathrm{NA}$ & 0.53 & $\mathrm{NA}$ \\
Benzene & $\mu \mathrm{g} / \mathrm{L}$ & 0.01 & 0.005 (EPA) \\
Cation Exchange Capacity & $\mathrm{meq} / 100 \mathrm{ml}$ & 10.3 & $\mathrm{NA}$ \\
Oil \&Grease & $\mathrm{mg} / \mathrm{L}$ & 48 & 10 EQA B \\
\hline NA= Not available & EQA B is for Malaysian Environmental Quality Act Standard B
\end{tabular}

$\mathrm{NA}=$ Not available

EQA B is for Malaysian Environmental Quality Act Standard B

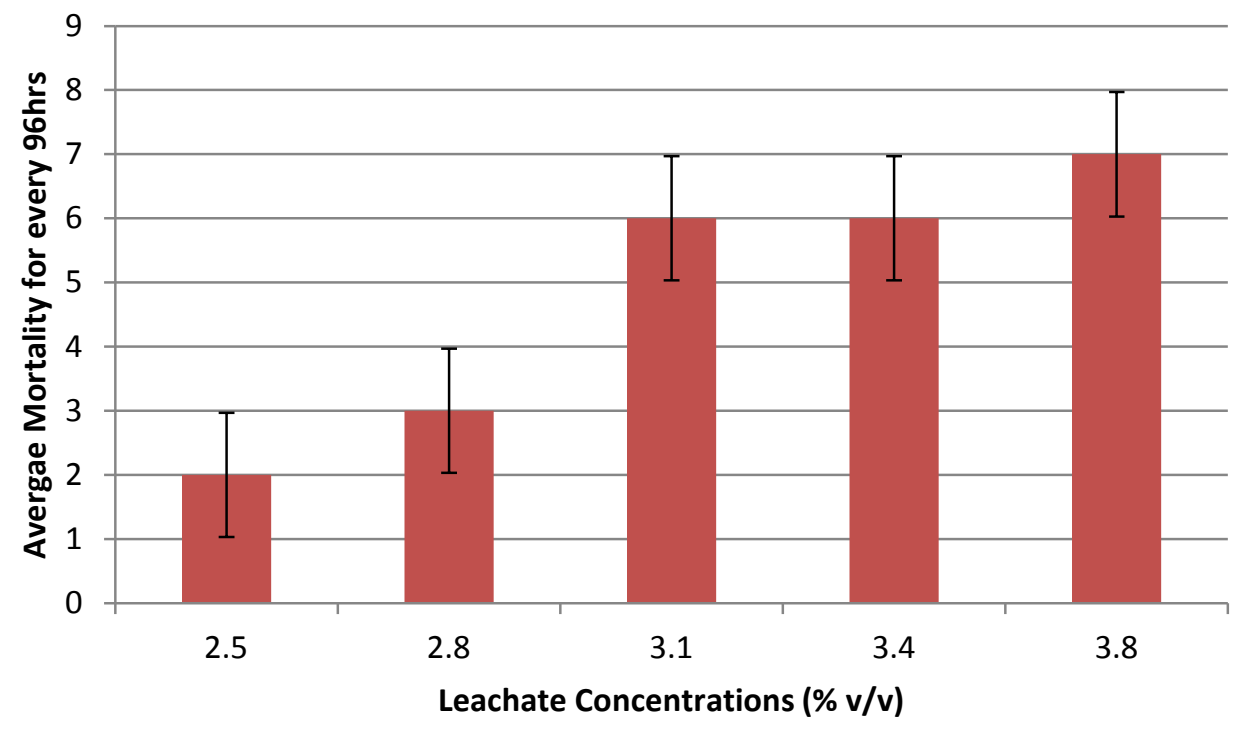

Figure 1. Total mortality distribution of the across different concentrations of the raw leachate at 96 hour interval 


\section{CONCLUSION}

This study concludes that based on the physicochemical analysis of the raw leachate, there is high concentration of organic matter in the leachate of an active landfill like JSL. Most of the constituents have toxic potentials and can cause harm to the environment via surface water pollution. In fact the leachate was toxic to edible fish since it killed O.mossambicus even at low concentrations (LC50 was $3.2 \% \mathrm{v} / \mathrm{v})$. It also affected the normal activity of the fish negatively, hence the behavioural changes in the fish.

\section{ACKNOWLEDGEMENT}

Authors wish to acknowledge Institute of Research Management and Monitoring, University of Malaya for funding this research (P0071/2009B). Also the invaluable contribution of Worldwide Landfills Sdn. Bhd. in supplying the leachate is appreciated.

\section{REFERENCES}

1. Holmlund, C. and Hammer, M. (1999). Ecosystem services generated by fish populations. Ecological Economics, Vol 29 (2): $253-268$.

2. Knudby, A., Brenning, A. and LeDrew, E. (2010). New approaches to modeling fishhabitat relationships. Ecological Modelling, Vol 221 (3): 503 - 511.

3. Delpech, C., Courrat, A., Pasquaud, S., Lobry, J., LePape , O., Nicolas, D., Boet, P., Girardin, M. and Lepage, M. (2010). Development of a fish-based index to assess the ecological quality of transitional waters: The case of French estuaries. Marine Pollution Bulletin, Vol 60 (6): 908 - 918.

4. Agamuthu, P., Fauziah, S. and Khidzir, K. M. (2009). Evolution of Solid Waste Management in Malaysia: Impacts and implications of the Solid waste bill, 2007.
Journal of Material Cycles of Waste Management, 11:96-103

5. Jaffar, Y., Lee, Y. and Salmijah, S. (2009). Toxicity Testing and the effect of landfill leachate in Malaysia on Behaviour of Common Carp (Cyprinus carpio L., 1758; Pisces, Cyprinidae). American Journal of Environmental Sciences, 5 (3): 209-217.

6. Ludwig, C., Hellwed, S., and Stucki S. (2003). Municipal Solid Waste Management: Strategies and Technologies for Sustainable Solutions. Springer-Verlag Berlin Heidelberg, New York.

7. Christensen, T., Kjeldsen, Bjerg, P., Jensen, D., Christensen, B., Baum, A. and Albrechtsen, H. (2001). Biogeochemistry of landfill leachate plumes. Applied Geochem., 16: 659-718. DOI: 10.1016/S08832927(00)00082-2.

8. Schwarzbauer, J., Heim, S., Brinker, S. and Littke, R. (2002). Occurrence and alteration of organic contaminants in seepage and leakage water from a waste deposit landfill. Water Resources., 36: 2275-2287. DOI: 10.1016/S0043-1354(01)00452-3.

9. Paxeus, N. (2000). Organic compounds in municipal landfill leachates. Water Science and Technology, 42: 323-333.

10. Bae, J., Kim, S. and Chang, H. (1997). Treatment of landfill leachates: ammonia removal via nitrification and denitrification and further COD reduction via fenton's treatment followed by activated sludge. Water Science and Technology., 36: 341348. Doi: 10.1016/S0273-1223(97)00736-1.

11. Selic, E., Wangi, C., Boes, $\mathrm{N}$ and Herbell, J. (2007). Biodegradability of Leachates from Chinese and German Municipal Solid Waste. Journal of Zhejiang UniversityScience B, 8, no 1, pp 14-19. 
12. Eun-ah, C., Kazuo, T., Masataka, H., Tatsuyoshi, Y. and Sotaro, H. (2009). Toxicological evaluation of the chemical oxidation methods for landfill stabilization. Journal of Waste Management, 9(3):10061011.

13. Sisinno, C., Oliveira-Filho, C., Dufrayer, E., Moreira, J. and Paumgartten, F. (2000). Toxicity evaluation of a municipal dump leachate using zebrafish acute tests. Bulletin Environmental Contamination Toxicology, 64: 107-113.Doi: 10.1007/s001289910017.

14. Osaki, K., Shosaku, T., Norihisa and Yoshiro, O. (2006). Toxicity testing of leachate from waste landfills using Medaka (oryzias latipes) for monitoring environmental safety. Environmental Monitoring and Assessment, 117: 73-84. DOI: $10.1007 / \mathrm{s} 10661-006-7670-\mathrm{x}$

15. Wong, M., (1989). Toxicity test of landfill leachate using Sarotherodon mossambicus (freshwater fish). Ecotoxicology and Environmental Safety, 17: 149-156. DOI: 10.1016/0147-6513(89)90033-X.

16. American Public Health Association (APHA) (2008). Standard Methods for the Examination of Water and Wastewater, $20^{\text {th }}$ Edition, American Public Health Association, Washington D.C.

17. United States Environmental Protection Agency (USEPA) (2000). Effluent Limitations Guidelines, Pretreatment Standards, and New Source Performance Standards for the Landfills Point Source Category, 65, no 12. pp 3007 - 3051.

18. Chian, E., DeWalle, F. and Hammerberg, E. (1976). Effect of Moisture Regime and other Factors on Municipal Solid Waste Stabilization in Gas and Leachate from Landfills, U.S. EPA-600/0-76-004, pp.7385 .
19. Enviromental Quality Act 1974 (Act 127) and Subsidiary Legislation, 2007. Laws of Malaysia. 120-155

20. Svobodova, Z, Lloyd, R., Machova, J. and Vykusova, B. (1993). Water Quality and Fish Health. EIFAC Technical Paper. NO 54.Rome FAO.

21. Alabaster, J. and Lloyd, R. (1980) .Water Quality Criteria for Freshwater Fish. Butterworths. 